\title{
FLOOD DISASTER MITIGATION THROUGH CITIZEN LAWSUIT
}

Mulyani ZULAEHA (iD) $1 *$

\section{Lies ARIANY (iD ${ }^{2}$}

\author{
Akhmad HENDRYAN DWIFAMA (iD ${ }^{3}$ \\ Rizka Annisa FALMELIA (iD 4 \\ Muhammad SHOFWAN RIDHANI (iD $^{5}$ \\ 1 Lambung Mangkurat University, Faculty of Law, mulyani.zulaeha@ulm.ac.id *Correspondent Author. \\ ${ }^{2}$ Lambung Mangkurat University, Faculty of Law, lies.ariany@ulm.ac.id \\ ${ }^{3}$ Lambung Mangkurat University, Faculty of Law, fama.hendry@gmail.com \\ 4 Lambung Mangkurat University, Faculty of Law, rizkaannisafalmelia@gmail.com \\ 5 Lambung Mangkurat University, Faculty of Law, mshofwan.ridhani@gmail.com
}

\section{Article history:}

Submission 18 August 2021 Revision 03 November 2021

Accepted 16 December 2021 Available online 31 December 2021

\section{Keywords:}

Disaster Mitigation,

Flood,

Citizen Lawsuit.

DOI:

https://doi.org/10.32936/pssj.v5i3.276

\begin{abstract}
A b s t r a c t
The state is responsible for providing protection and management in accordance with the authority it has so that environmental damage does not occur that causes flooding and is able to anticipate the possibility of flooding again in the future. However, in practice it cannot be denied that state administrators, in this case the central government to local governments, have the possibility of committing a mistake as an act against the law because it does not provide fulfillment of the rights of citizens, so that the community can sue the state for that mistake. Citizen lawsuits do not lead to claims for losses, but demands in the form of issuing general policies by the government. The purpose of this study is to find out about the efforts of citizens to obtain protection from the threat of flooding through the citizen lawsuit mechanism and to find out how the potential citizen lawsuit mechanism in resolving floods so that it does not happen again. This study uses a normative juridical approach by using perspective analysis. The results showed that the problem of flooding resulted in citizens not getting their rights to a good and healthy environment. The citizen lawsuit is carried out so that state officials issue a general regulatory policy as a preventive one (disaster mitigation) so that floods do not occur again in the future.
\end{abstract}

\section{Introduction}

Indonesia is based on its astronomical location between $6^{\circ} \mathrm{N}-11^{\circ} \mathrm{S}$ and $95^{\circ} \mathrm{E}-141^{\circ} \mathrm{E}$. Based on the astronomical location as in the picture above, Indonesia is a country that has a tropical climate. Based on its geographical location, Indonesia is a country that has a high potential for earthquakes, tsunamis, volcanic eruptions and landslides. The territory of the Unitary State of the Republic of Indonesia is a disaster-prone area. Its position which is located on the equator and in the Pacific Ring of Fire area poses a high potential for various types of hydro meteorological-related disasters, such as floods, droughts, extreme weather, extreme ocean waves or tsunamis, coastal abrasion, and forest fires (Moerwanto \& Zulfan, 2020). The position of Indonesia's territory, which is on the equator and in the form of an archipelago, also creates a high potential for various types of hydro meteorological disasters, namely floods, flash floods, droughts, extreme weather (hurricanes), abrasion, extreme waves and land and forest fires. The phenomenon of climate change contributes to the increase in hydro meteorological disasters. Indonesia is located between two oceans, namely the Indian Ocean and the Pacific Ocean, besides that, Indonesia is also crossed by a ring of fire, which also causes Indonesia to become an area that is very prone to natural disasters, such as earthquakes, tsunamis, volcanic eruptions, volcanoes, floods, landslides, strong winds, etc.

Based on Law Number 24 of 2007 concerning Disaster Management, Indonesia has 12 types of high-risk disasters, namely earthquakes, tsunamis, volcanic eruptions, land movements or landslides, floods, flash floods, droughts, extreme 
weather or tornadoes, extreme waves and abrasion, forest and land fires, epidemics and disease outbreaks, and technological failures. With the disaster conditions combined with the high vulnerability of the Indonesian people, the risk of disaster in Indonesia is included in the very high category.

One of the most common disasters is flooding. Flood is an event that overflows water from the riverbank boundary in a relatively short period or an event that inundates water on the ground surface until it exceeds a certain time limit, which results in losses. In the regions of Indonesia, flood disasters occur most frequently and are repeated every year, especially during the rainy season (Suripin, 2004). The problem of flooding itself has arisen since humans have lived and have also carried out various activities in the area in the form of a flood (flood plain) of a river. The condition of the land in this area is generally fertile and holds various potentials and conveniences so that it has a high attractiveness for cultivation. In addition to providing benefits to human life, floodplains also contain the potential for harm in connection with the threat of flooding in the form of flooding that can cause damage and disasters. Along with the growth rate of development in floodplains, the potential for damage and disasters has also increased from time to time (Kumalawati \& Angriani, 2018).

Besides being caused by natural factors, namely high rainfall, floods also occur due to human activities. Other factors causing flooding are population growth, irregular urban spatial planning, unavailability of urban infrastructure and irregular use of land use resulting in increased flooding problems, especially in urban areas. Thus, flood disasters can be influenced by three elements, namely meteorological elements, elements of physical characteristics of watersheds (DAS) and human elements.

Indeed, the occurrence of flood disasters if observed is very local in nature, because it could be that one area is flooded and the other area is safe and does not flood. Even though it is a local disaster, sometimes floods can also spread and paralyze community activities. Therefore, in line with the causes of this flood, the most important thing at this time is to take quick steps to handle and overcome this flood disaster. So that people affected by this flood disaster immediately get help. In addition, to prevent similar incidents from happening in the years to come. Moreover, from the legal aspect, there is already a basis for the Government and local governments to act in dealing with the flood disaster. For this reason, the Government and Regional Governments need to formulate responsive policies related to flood prevention and mitigation.
The public can claim for material and immaterial damages through a lawsuit. However, it should be realized that such a lawsuit would not have a direct impact on policy changes regarding flood anticipation. It will not be as easy as imagined to prove the government's guilt. This is important because Indonesia's environment must be protected and managed properly based on the principles of state responsibility, the principle of sustainability, and the principle of justice. In addition, environmental management must be able to provide economic, social and cultural benefits that are carried out based on the principles of prudence, environmental democracy, decentralization, as well as recognition and respect for local wisdom and environmental wisdom.

The Unitary State of the Republic of Indonesia is responsible for protecting the entire Indonesian nation and the entire homeland of Indonesia with the aim of providing protection for life and livelihood, including protection against disasters, in the context of realizing public welfare based on Pancasila, as mandated in the 1945 Constitution of the Republic of Indonesia. The state is responsible for providing protection and management in accordance with the authority it has so that environmental damage does not occur that causes flooding and is able to anticipate the possibility of flooding again in the future.

However, in practice it cannot be denied that state administrators, in this case the central government to local governments, there is a possibility of committing a mistake as an act against the law because it does not provide fulfillment of the rights of citizens, thus the State may also be sued for For that mistake, the state was punished for taking certain actions or issuing a policy that was general in nature so that such negligence would no longer occur in the future (Kurniawan, 2016), therefore, in this paper, we try to examine the efforts to prevent and manage floods through a citizen lawsuit mechanism. Citizen lawsuits do not lead to claims for losses, but demands in the form of issuing general policies by the government. Based on the description above, it is interesting to conduct a discussion about the efforts of citizens to obtain protection from the threat of flooding through the citizen lawsuit mechanism and how the potential citizen lawsuit mechanism in resolving floods so that it does not happen again. 


\section{Results and Discussion}

\subsection{Responsibilities and Authorities of the}

Government and Local Governments in

Preventing and Reducing the Impact of

Disasters through Environmental

\section{Management}

The fourth paragraph of the Preamble to the 1945 Constitution of the Republic of Indonesia mandates that the Government of the Republic of Indonesia protect the entire nation and the entire homeland of Indonesia, promote public welfare, educate the nation's life and participate in carrying out world order based on freedom, eternal peace and social justice. As the implementation of the mandate, national development is carried out which aims to create a just and prosperous society that always pays attention to the right to livelihood and protection for every citizen within the framework of the unitary state of the Republic of Indonesia. Therefore, as a unified country, the goals of this country must also be realized from the central government to the local government level.

Therefore, as a unitary State of the Republic of Indonesia which has a wide area and is located on the equator at a cross position between two continents and two oceans with natural conditions that have various advantages, but on the other hand its position is in an area that has geographical, geological, hydrological, and demographics that are prone to disasters with a fairly high frequency, thus requiring systematic, integrated, and coordinated handling.

Indonesia realizes that disaster issues must be taken seriously. Disaster is a very comprehensive and multi-dimensional discussion. Responding to disasters whose frequency continues to increase every year, thoughts on disaster management must be understood and implemented by all parties. Disasters are everyone's business. Periodically, Indonesia builds a national disaster management system (Disaster Management Agency). Also included in the handling of one of the flood disasters that do not escape threatening Indonesia. Therefore, this demands responsibility up to the local government level to solve it.

The government together with the local government are the servants needed by the community in overcoming floods. For this reason, it is hoped that the direct role of the Government and Regional Government is expected to do concrete things that reduce flooding, such as making reservoirs that can accommodate rainwater while also providing garbage bins so that people do not litter and normalize rivers that this spread. In addition, the community must have awareness to protect the environment. The government and the community can work together to overcome floods and carry out reforestation or tree planting around vacant land.

So that an appropriate policy must be taken immediately to overcome it. Therefore, moreover, the local government is the person in charge of managing disasters that occur in their area. Flood handling and mitigation is the responsibility and authority of the government and local government as stated in Chapter III of Article 5 to Article 9 of Law no. 24 of 2007 concerning Disaster Management.

As for the responsibilities and authorities of the Government, there are Articles 6 and 7, which read:

Article 6

The Government's responsibilities in the implementation of disaster management include:

a) disaster risk reduction and integration of disaster risk reduction with development programs;

b) protection of the community from the impact of disasters;

c) guaranteeing the fulfillment of the rights of communities and refugees affected by disasters fairly and in accordance with minimum service standards;

d) recovery of conditions from the impact of disasters;

e) allocation of budget for disaster management within the state budget for adequate revenues and expenditures;

f) budget allocation for disaster management in the form of ready-to-use funds; and

g) maintenance of authentic and credible archives/documents from disaster threats and impacts.

Article 7

1. Government authorities in the implementation of disaster management include:

a) determination of disaster management policies in line with national development policies;

b) making development plans that include elements of disaster management policies;

c) determination of the status and level of national and regional disasters;

d) determination of cooperation policies in disaster management with other countries, agencies, or other international parties;

e) formulation of policies regarding the use of technology that has the potential as a source of threat or disaster hazard; 
f) the formulation of policies to prevent the control and exploitation of natural resources that exceeds the ability of nature to carry out restoration; and

g) gcontrolling the collection of money or goods of a national nature.

2. The determination of the status and level of national and regional disasters as referred to in paragraph (1) letter c contains indicators that include:

a) number of victims;

b) property loss;

c) damage to infrastructure and facilities;

d) wide coverage of disaster-affected areas; and

e) the socio-economic impact.

3. Further provisions regarding the determination of the status and level of disaster as referred to in paragraph (2) shall be regulated by a presidential regulation

Furthermore, the responsibilities and authorities of local governments are regulated in Articles 8 and 9 of Law no. 24 of 2007 concerning Disaster Management.

As for Article 8 which states:

Local government responsibilities in disaster management include:

a) guaranteeing the fulfillment of the rights of the community and refugees affected by the disaster in accordance with the minimum service standards;

b) protecting the community from the impact of the disaster;

c) disaster risk reduction and integration of disaster risk reduction with development programs; and the allocation of disaster management funds in an adequate regional revenue budget.

Then Article 9 states:

The authority of the local government in the implementation of disaster management includes:

a) stipulation of disaster management policies in the region in line with regional development policies;

b) making development plans that include elements of disaster management policies;

c) implementation of cooperation policies in disaster management with other provinces and/or districts/cities;

d) regulation of the use of technology that has the potential as a source of threat or disaster hazard in its territory; e) formulating policies to prevent the control and depletion of natural resources that exceed the natural capacity of the territory; and

f) controlling the collection and distribution of money or goods in its territory.

In Law no. 24 of 2007 concerning Disaster Management further stipulates that every region in an effort to cope with disasters, has a disaster management plan, then this is followed up with further arrangements through Government Regulation no. 21 of 2008 concerning the Implementation of Disaster Management. In connection with the above, in the context of handling the flood problem, it is necessary to follow up through PP No. 21 of 2008 is related to regulations from the government regarding the implementation of disaster management, the scope of which includes:

a) all flood disaster management efforts carried out during pre-disaster, during emergency response, and post-disaster;

b) emphasis on preventive measures in pre-disaster actions prior to the occurrence of floods;

c) providing easy access for flood disaster management agencies during emergency response; and

d) implementation of rehabilitation and reconstruction efforts in post-flood disasters.

Floods that occur in almost all regions in Indonesia should not escape the attention of the Government and Regional Governments, because Indonesia is one of the areas prone to disasters such as land and forest fires during the dry season, then like now during the rainy season floods occur. Which in midJanuary 2021 to April 2021 floods hit Indonesia.

In order to prevent and reduce the negative impacts of natural disasters, including floods, the thing that deserves attention is efforts to continue to maintain and manage the environment. Because in fact the environment if managed properly will ensure the survival of the current generation to the generations to come. Through the preservation of this environmental function, it is hoped that it can support the sustainability of human life and other living things together. while on the other hand it is hoped that the creation of an environmental capacity that is able to absorb substances, energy, and/or other components that enter or be incorporated into it.

So that the flood disaster does not keep repeating itself every year, this requires greater efforts to anticipate it, so that losses can be minimized. It is necessary that there are various government efforts that are structural in nature (structural approach), in order to be able to overcome the problem of flooding in Indonesia. It 
must be admitted that flood control has so far been more focused on providing physical flood control buildings to reduce the impact of disasters. In addition, although non-physical policies which generally include community participation in flood management have been made, they have not been implemented properly, even not according to community needs, so their effectiveness is questioned. Sectoral, centralized, and top-down policies without involving the community are no longer in line with global developments that demand decentralization, democracy, and stakeholder participation, especially disaster-affected communities (Bappenas, 2008).

Environmental management plays an important role in preventing and reducing the impact of disasters through environmental management. President Joko Widodo has stated that disaster prevention and prevention is not enough just to build infrastructure physically. because of environmental management, this is no less important to pay attention to (Public Relations Ministry Of State Secretariat, 2020).

A good and healthy environment is a human right and constitutional right for every Indonesian citizen, therefore, the state, government and all stakeholders are obliged to protect and manage the environment in the implementation of sustainable development so that the Indonesian environment can remain a source and source of protection for the environment. life support for the Indonesian people and other living creatures. For this reason, the ability of a harmonious and balanced environment should be preserved, so that any changes made need to be accompanied by efforts to achieve environmental harmony and balance at a new level. Preservation of harmonious and balanced environmental capabilities leads to harmony between development and the environment, so that the two cannot be contradicted with each other (Bethan, 2008).

Law No. 23 of 2009 concerning Environmental Protection and Management is the legal umbrella that forms the basis for making policies regarding environmental issues in Indonesia. Therefore, all further regulations related to the environment both at the level of laws, government regulations and other implementing regulations which are instruments of wisdom (Instrumenten Van Beleid) must be in line with Law no. 23 of 2009.

Humans grow and develop with the environment around them. Every human interaction, both among humans and with the environment, will have an impact on the environment, both positive and negative. Therefore, a legal rule is designed to regulate the balance of humans and the environment in which they live. Environmental law regulates environmental patterns along with all devices and conditions with humans that exist and affect the environment (Daud Silalahi \& Lawencon Associates). It is clear that the role of the environment is very important for human life and other living things. If seen, this is a manifestation of human rights as stated in the 1945 Constitution of the Republic of Indonesia that a good and healthy environment is a human right and a constitutional right for every Indonesian citizen. How can this right be realized if it is not accompanied by responsibility? Therefore, the state, government and all stakeholders are obliged to protect and manage the environment in the implementation of sustainable development so that the Indonesian environment can remain a source and life support for the Indonesian people and other living creatures.

\subsection{Citizen Lawsuit in Flood Disaster Prevention and Management (Disaster Mitigation)}

Indonesia continues to carry out development for the sake of the people's prosperity, but in carrying out development it must pay attention to aspects of integration with the environment, therefore in development the thing that should be remembered is integration in synchronizing, integrating and giving equal weight to the three main aspects of development, namely the economic aspect, socio-cultural aspects and environmental aspects. The idea behind it is that economic, socio-cultural and environmental development should be viewed as closely related to each other, and therefore the elements of this interrelated whole should not be separated or contradicted one another. Basically, what is to be achieved with sustainable development is to shift the emphasis of development from only economic development, to also include socio-cultural and environmental development (Keraf, 2005).

The inability of the government and local governments to carry out development by combining economic, socio-cultural and environmental aspects will lead to imbalances that ultimately threaten the environment, which can lead to disasters. The process and consequences of natural disasters clearly threaten the safety of society at large. Therefore, the prevention, handling, and management of natural disasters requires the presence of the state. In other words, the government together with the provincial and district/city governments must play a direct role in disaster mitigation measures because natural disasters are not an individual matter but involve public safety (Heriyati, 2020).

It must be realized that human behavior greatly affects nature, therefore humans need to have firm principles in order to be able to protect the environment properly and obey the established regulations, in order to create order and preserve the environment. Law Number 32 of 2009 concerning Environmental Protection and Management is the legal umbrella in the environmental field 
in Indonesia, therefore Law Number 32 of 2009 concerning Environmental Protection and Management is the basis for adjustments to existing regulations, and make it as a complete provision in a system.

So that the environment can be well maintained, it is also necessary to carry out an effort to protect and manage the environment. Therefore, the Government and regional governments that have the authority in environmental management must be able to carry out enforcement in the field of environmental law. Although the process in enforcing environmental law is much more complicated and complex when compared to other offenses, because environmental law is a functional legal field in which there are elements of administrative law, civil law and criminal law.

In order for this environmental law enforcement to be implemented, the government and local governments must make a set of regulations and policies in the context of environmental protection and management so as to avoid various natural disasters, especially floods. Through a set of regulations and policies, it would be one of the efforts to support environmental law enforcement. It must also be realized that in the context of law enforcement, it must be able to balance the public interest and also consider the implementation of national and regional development together. This is indeed a difficult task for the government and local governments, therefore it must be carried out wisely and wisely. Thus the occurrence of this flood can be prevented in such a way through the regulations and policies made.

The natural wealth contained must be able to be managed as well as possible lest the government and local governments make mistakes in their management. For this reason, things that should be emphasized are things that become the basis for making regulations and policies in the field of the environment in order to prevent and cope with the flood disaster that occurs, it is possible to observe the provisions of Article $28 \mathrm{H}$ paragraph (I), Article 33 paragraph (3), (4) and (5) the 1945 Constitution, which if we look at it, there are 5 important things that become state legal policies in environmental management and natural resource utilization (Kurniawan, 2016):

a) Environmental management and utilization of natural resources must be placed within the framework of recognizing, protecting and fulfilling the human rights of every citizen to a good and healthy environment. In other words, the human right to a good and healthy environment cannot be sacrificed due to the implementation of development and utilization of natural resources. b) The management of the environment and the use of natural resources are the responsibility of the state, where through the right to control the state, the state makes rules and policies for the use of the environment and natural resources.

c) The welfare of the people becomes the philosophical and sociological basis for all activities and activities of environmental management and utilization of natural resources for the welfare of the people.

d) Environmental management and utilization of natural resources is a means to achieve sustainable development with an environmental perspective, in the sense that the objectives of environmental management and utilization of natural resources include not only people's welfare, but also aspects of environmental sustainability and national economic progress.

e) There is a delegation of further regulations regarding environmental management by law.

It should be based on 5 important things that become state legal policies in environmental management and utilization of natural resources: above, the government together with local governments can make a plan, arrangement and even realize guarantees for better environmental protection and management. good. Therefore, it is hoped that the local government with this set of existing regulations will allow the government to plan, regulate and even realize the guarantee of legal protection to citizens for a good and healthy environment (Sharananingtyas, 2016).

But the fact is that from January 2021 to April 2021 there were floods that hit various regions in Indonesia. Apart from the weather factor, environmental and human rights (HAM) experts argue that the government's negligence factor is quite large in this flood case and this opens the potential for civil society to file lawsuits for the floods that occurred. The destruction of forests in Indonesia due to massive mining and oil palm plantations has caused great losses to the community so that community members can hold local governments accountable.

The flood disaster that spread across Indonesia, of course, very many people were affected and suffered losses so that the basic rights of the community were not fulfilled by the State, both in the form of rights to the environment, rights to decent housing, rights to work because they could not It is undeniable that many people are affected by their work and lose their jobs, as well as the right to health so that people have the possibility to claim and get compensation for losing their basic rights. Therefore, community members can demand accountability from local 
governments to conduct evaluations as well as review mining permits and oil palm plantations that are rife so that they can overcome this flood disaster and prevent further environmental damage so that it does not get worse.

The paradigm shift implied in Law Number 24 of 2007 concerning Disaster Management is that disasters are not responded to in the form of an emergency response (reactive in nature), towards disaster mitigation (anticipatory in nature) as part of a risk management pattern. Disaster mitigation is a series of efforts to reduce disaster risk, both through physical development, socialization to increase awareness and increase community capacity in dealing with disasters. According to Westen (2005), disaster mitigation can be divided into two, namely:

\section{Structural Mitigation}

That refers to physical development to reduce or avoid the impact of hazards including technical steps, hazard-resistant construction and infrastructure that is able to protect against hazards

\section{Non Structural Mitigation}

Namely reducing the impact caused by the threat of harm to the community by referring to policies, awareness, knowledge development, community commitment, methods, including participatory mechanisms, modifying vulnerability, damage, harm and disturbance.

One form of disaster mitigation that is relevant to the government's responsibility is non-structural mitigation in the form of policies. The form of disaster mitigation that is manifested in the form of public policy is government activities to solve problems in the community either directly or through institutions, in the case of flooding problems, the purpose of issuing policies is for the welfare of the community through regulations made by the government in the form of nonrecurrence of flood disasters or minimizing the impact of floods. flood disaster for the community. The policy steps that can be taken by the government are in the form of a strategy for implementing spatial planning as an effort to reduce disaster risk, through zoning regulations that are implemented consistently, emphasis on controlling space use systemically through stipulating zoning regulations, licensing, providing incentives and disincentives, and imposing sanctions. Besides, it also needs to be supported by strict and consistent law enforcement related to spatial order.

The dimension of spatial planning which is one of the government's obligations is the dimension of space utilization and control over the use of space. In addition, the government must also conduct a mapping study of the area based on the level of flood risk, analysis of the level of vulnerability to flood hazards, determination of flood risk zoning, flood hazard maps become the basis for the government to issue policies related to development. Mitigation should be a guideline for the government in making development planning.

Development that is carried out without being based on a disaster mitigation strategy can result in losses and not protect citizens from feeling safe from the threat of danger originating from natural disasters. Not protected from getting the right to a good and healthy environment as a citizen's human right. As stated in the 1945 Constitution of the Republic of Indonesia Article $28 \mathrm{H}$ paragraph (1), it is stated that "every person has the right to live in physical and spiritual prosperity, to live and to have a good and healthy living environment and the right to health services". Furthermore, this provision is implemented in Article 65 paragraph (1) of Law Number 32 of 2009 concerning Environmental Protection and Management, which states "everyone has the right to a good and healthy environment as part of human rights", as well as in Law No. Law Number 39 of 1999 concerning Human Rights, Article 3 states "the community has the right to a better and healthier environment". The meaning of this provision is that the state guarantees the right to a good and healthy environment as a constitutional right for every Indonesian citizen so that everyone is protected from pollution that can endanger public health.

The State Administrators of the Republic of Indonesia are the bearers of the mandate of the Preamble of the 1945 Constitution, namely to protect, promote, enforce and guarantee the fulfillment of the human rights of every citizen of the Republic of Indonesia. As emphasized in the body of the 1945 Constitution, namely Article 28 I paragraph (4) of the 1945 Constitution, "The protection, promotion, enforcement and fulfillment of human rights are the responsibility of the state, especially the Government". Law Number 39 of 1999 concerning Human Rights (HAM), Article 8, "Protection, promotion, enforcement, and fulfillment of human rights are primarily the responsibility of the Government".

The state is responsible for the fulfillment of these citizens' human rights. Country. If the government ignores the fulfillment of these rights then in principle the government has committed an unlawful act. In environmental problems, if the government acts recklessly that causes environmental damage, either in the form of setting regulations that lead to losses suffered by the community, or with its authorities on behalf of the public interest to change the use of the environment and ultimately have an impact on flooding (Isrok \& Birham, 2010). 
One of the possible steps so that citizens can prove that the government has not carried out their obligations and responsibilities is through a citizen lawsuit as a step to fulfill the rights of citizens by asking the local government to carry out environmental rehabilitation and can request that the local government issue a policy to environmental recovery and anticipation of future damage (Satriastanti, 2021). Citizens' right to sue for the public interest departs from the awareness to guard the protection of human rights. is a lawsuit mechanism as an embodiment of individual access / individual citizens for the benefit of the entire citizen or the public interest to sue the responsibility of state administrators for negligence in fulfilling the rights of citizens? The negligence was argued as an act against the law in fulfilling the rights of citizens, so that a citizen lawsuit was filed within the scope of the general court in this case a civil case.

The elements in the citizen lawsuit as an effort to overcome flooding to get a good and healthy environment, among others:

a) Every person or every citizen Every person essentially does not get an obstacle to be able to file a citizen lawsuit, because everyone has the standing to file a lawsuit without requiring a real and direct loss to him, by proving that he is an Indonesian citizen.

b) Public Interest, which is the main basis in a citizen lawsuit. The problem of flooding is a disaster that has brought many consequences in the form of health and even death.

c) Unlawful acts are in the form of negligence by state officials in dealing with floods, so that the impact is widespread and occurs in a matter of months, so that people do not get a healthy environment.

d) Petitum in a citizen lawsuit must contain a demand that the government issue a general regulatory policy to overcome.

Although the citizen lawsuit mechanism has not yet received a juridical basis in the form of Indonesian law, this system is better known in the common law legal system such as in the United States, India and Australia. Meanwhile, in the civil law legal system, it is more popular with the class action lawsuit system and legal standing. However, the three of them through citizen lawsuits, class actions and legal standing have similarities because they both involve the public/public/public interest. In particular, citizen lawsuits are generally lawsuits by a group of people who act in the name of the public interest to sue the state or state institutions that violate the law or fail to implement it, in which the plaintiffs are not allowed to demand material or immaterial compensation in the form of money. . but demands in the form of issuing general policies by the government (Zulaeha,
2017). However, the citizen lawsuit mechanism has been accepted in the justice system in Indonesia, as a form of step to resolve a problem.

The characteristic of a citizen lawsuit is that every citizen can file a lawsuit even though it does not have a causal relationship with the loss caused by the access of individual citizens for the public interest to file a lawsuit in court which is intended to protect citizens as a result of omission by the state against their rights. rights of citizens (Nugroho, 2010), so that the government or the state carries out law enforcement that is required of them to recover public losses that have occurred (Gumayra, 2006), by issuing a regulatory policy containing efforts to prevent flood disasters from occurring.

Over time, the lawsuit mechanism through citizen lawsuits has become more and more prominent in Indonesia. The presence of a lawsuit through a citizen lawsuit is an implication of the regulation of the human rights chapter in the constitution after the amendment to the 1945 Constitution, therefore the state is now required to actively provide guarantees and protections for human rights in Indonesia. Another implication is that human rights become the constitutional rights of citizens (Fatah, 2013).

Citizens' right to sue for the public interest departs from the awareness to guard the protection of human rights. Citizen lawsuit is a lawsuit mechanism as a manifestation of individual access / individual citizens for the benefit of the entire citizen or public interest to sue the responsibility of state administrators for negligence in fulfilling the rights of citizens. The negligence is argued to be an act against the law in fulfilling the rights of citizens, so that a citizen lawsuit is filed within the scope of the general court in this case a civil case (Zulaeha, 2017). Therefore, it should be noted that in the context of upholding human rights, proper handling of flood victims is a manifestation of the Government and local governments in the protection and fulfillment of human rights.

The right to a good and healthy environment is a human right also contained in the General Elucidation of Law Number 32 of 2009 concerning Environmental Protection and Management, namely "The 1945 Constitution of the Republic of Indonesia states that a good and healthy environment is a human rights and constitutional rights for every Indonesian citizen. Therefore, the State, government and all stakeholders are obliged to protect and manage the environment in the implementation of sustainable development so that the Indonesian environment can remain a source and life support for the Indonesian people and other living creatures." 


\section{Conclusions}

Citizen Lawsuit is the right step to use in order to resolve flood disasters caused by mistakes/negligence of state administrators in providing protection for citizens to get the right to a good and healthy environment as part of human rights. Through the citizen lawsuit mechanism, a general regulatory policy will be obtained to prevent the recurrence of flood disasters in the future. The potential for using the citizen lawsuit mechanism as an effort to overcome flooding is a necessity because the demands requested by citizens in their lawsuits are for the government to issue regulations in the form of laws, implementing regulations, or take certain other actions as a preventive effort (disaster mitigation).

The citizen law suit mechanism is not yet regulated in Indonesia, this mechanism is really needed as a control over government policies that ignore or violate the fulfillment of human rights, especially economic, social and cultural rights. In the development of state life, there are not a few indications of negligence or neglect by government authorities that can harm citizens. The people as the holder of sovereignty should have the space to sue the government in order to achieve justice. Several laws and regulations have mandated the protection of the interests of citizens. In this case, it is possible for the Constitutional Court of the Republic to examine, hear and decide on citizen lawsuits using the basis of the Law on Judicial Power. However, the state should revise the Constitutional Court Law by adding the authority of the Constitutional Court. In addition, a further effort is that it is necessary to carry out the Fifth Amendment of the 1945 Constitution.

\section{References}

1. Bappenas.go.id. (2008). Kebijakan Penanggulangan Banjir Di Indonesia" (Deputi Bidang Sarana dan Prasarana, Direktorat Pengairan dan Irigasi). Available at: https://www.bappenas.go.id/files/5913/4986/1931/2k ebijakan-penanggulangan-banjir-diindonesia_20081123002641_1.pdf (Accessed April 2, 2021)

2. Bethan, S. (2008). Penerapan Prinsip Hukum Pelestarian Fungsi Lingkungan Hidup Dalam Aktivitas Industri Nasional (Sebuah Upaya Penyelamatan Lingkungan Hidup Dan Kehidupan Antar Generasi. Bandung, Alumni.

3. BNPB.com. Sistem Penanggulangan Bencana. Available at: https://bnpb.go.id/sistempenanggulangan-bencana (Accessed February 8, 2021)

4. Daud Silalahi \& Lawencon Associates. Hukum Lingkungan Dan Penegakannya Di Indonesia.
Available

https://www.dslalawfirm.com/id/hukum-lingkungan/

Admin DSLA, "Hukum Lingkungan Dan Penegakannya Di Indonesia,” (accessed January 25, 2021)

5. Fatah, A. (2013). Gugatan Warga Negara Sebagai Mekanisme Pemenuhan Hak Asasi Manusia Dan Hak Konstitusional Warga Negara. Yuridika, 23(3). http://dx.doi.org/10.20473/ydk.v28i3.347

6. Gumayra, D.K. (2006). Panduan Bantuan Hukum di Indonesia. Jakarta, Aussaid YLBHI, PSHK dan IALDF.

7. Heriyati, S. (2020). Peran Pemerintah Daerah Dalam Penanggulangan Bencana, Jurnal Pemerintahan Dan Keamanan Publik. Jurnal Pemerintah dan Keamanan ublik (JP Dan KP), 2(2), 139-146. https://doi.org/10.33701/jpkp.v2i2.1088

8. Isrok and Birham, R.E. (2010). Citizen Lawsuit. Malang, Universitas Brawijaya Press.

9. Keraf, A.S. (2005) Pembangunan Berkelanjutan Atau Berkelanjutan Ekologi Dalam Hukum Dan Lingkungan Hidup Di Indonesia. Yogyakarta, UII Press.

10. Kumalawati, R. \& Angriani, P. (2018). Mitigasi Bencana: Studi Kasus Banjir Di Kabupaten Hulu Sungai Tengah. Yogyakarta, Penerbit Ombak.

11. Kurniawan, R.R. (2016). Urgensi Pengaturan Citizen Lawsuit Terhadap Permasalahan Lingkungan Dalam Kerangka Hak Asasi Manusia (Studi Terhadap Bencana Asap Tahunan Di Provinsi Riau). Yogyakarta, Universitas Islam Indonesia.

12. Moerwanto, A.S. \& Zulfan, J. (2020). Mitigasi Bencana Alam Pada Infrastruktur Jalan Dan Jembatan. Jurnal HPJI (Himpunan Pengembangan Jalan Indonesia), $\quad 6(1), \quad$ 1-14. https://doi.org/10.26593/jh.v6i1.3730.1-14

13. Nugroho. S.A. (2010). Class Action dan Perbandingannya Dengan Negara Lain. First Printed. Jakarta, Prenadia Media Group.

14. Public Relations Ministry of State Secretariat. (2020). Cegah dan Kurangi Dampak Bencana dengan Pendekatan Ekologis. Available at: https://setneg.go.id/baca/index/cegah dan kurangi_d ampak bencana dengan pendekatan ekologis (Accessed February 8, 2021)

15. Satriastanti, F.E. (2021). Bagaimana Warga Bisa Ajukan Gugatan Hukum Terhadap Pemerintah Terkait Banjir Di Kalimantan Selatan. Available at: https://theconversation.com/bagaimana-warga-bisaajukan-gugatan-hukum-terhadap-pemerintah-terkait- 
banjir-di-kalimantan-selatan-153977 (accessed April 6, 2021)

16. Sharananingtyas, Y.N. (2016). Gugatan Warga Negara (Citizen Lawsuit) Dan Justiciability Pemenuhan Hak Atas Lingkungan Hidup Yang Baik Dan Sehat. Kertha Patrika 38(1), 31-42. Available at: https://ojs.unud.ac.id/index.php/kerthapatrika/article/ view/21532/14232

17. Suripin. (2004). Drainase Perkotaan yang Berkelanjutan. Yogyakarta, Andi Offset.

18. Western, V.C. (2005). Multihazard Risk Asessment. The Netherland:UNU-ITS-DGIM.ITS.

19. Zulaeha, M. (2017). Mengatasi Kabut Asap Melalui Mekanisme Citizen Lawsuit. Jurnal Hukum Lingkungan $\quad 3(1), \quad$ 87-106. https://doi.org/10.38011/jhli.v3i1.35 